\title{
Large Scale Direct Shear Box Tests on Gravels
}

\author{
Ali Anıl YUNATCI ${ }^{1}$ \\ Kemal Önder ÇETİN ${ }^{2}$
}

\begin{abstract}
Within the confines of this study, the results of direct shear box tests performed on poorly(GP) and well-graded (GW) gravel samples are presented. Samples are tested under effective normal stresses ranging from 77 to $205 \mathrm{kPa}$, and with initial void ratio ranging from 0.42 to 0.53 . The estimated peak secant-angles of shearing resistances vary in the range of 49 to 61 degrees. On the basis of the ratio of vertical to horizontal deformation rates, the peak angles of dilation are estimated as 10-16 degrees. These estimated values are concluded to be in coherency with available literature, other than the recommendations of Navfac DM 7.01.
\end{abstract}

Keywords: Murat River gravel, direct shear box test, peak angle of shearing resistance, dilation angle, void ratio.

\section{INTRODUCTION}

Owing to difficulties in testing gravels or coarser materials in conventional triaxial, simple shear or direct shear devices due to scale and/or membrane compliance effects, there exists relatively a limited number of studies regarding their engineering properties and straining responses. Liu (2009) summarizes the results of direct shear tests performed by using 122.5 $\mathrm{cm} \times 122.5 \mathrm{~cm}$ testing frames on rockfill materials with various compacted densities and $\mathrm{D}_{\max }$ values ranging from $200 \mathrm{~mm}$ to $300 \mathrm{~mm}$, which were tested under effective normal stresses reaching $260 \mathrm{kPa}$ (Matsuoka et. al., 2001; Liu et. al., 2004). Tests on rockfill materials of sandstone origin by using $80 \mathrm{~cm}$ x $80 \mathrm{~cm}$ sized frames are similarly presented in Wang et. al. (2016), along with case studies on soil - rock mixtures, which were tested in $50 \mathrm{~cm} \mathrm{x} 50 \mathrm{~cm}$ shear frames at a maximum effective normal stress of $250 \mathrm{kPa}$ (Li et. al., 2014). A different approach towards utilizing the conventional laboratory triaxial testing apparatus is summarized in Vasistha et. al. (2012), in which samples from river beds and blasted sources having maximum particle sizes ranging from $200 \mathrm{~mm}$ to $600 \mathrm{~mm}$ were used to create a downscaled gradation curve using parallel gradation techniques. In addition to large scale

Note:

- This paper was received on September 18, 2019 and accepted for publication by the Editorial Board on August 17, 2020.

- Discussions on this paper will be accepted by March 31, 2020.

- https://doi.org/10.18400/tekderg.606816

1 Geodestek Engineering and Consulting Co. Ltd., Ankara, Turkey - ayunatci@geodestek.com https://orcid.org/0000-0003-4279-0007

2 Middle East Technical University, Civil Engineering Department, Ankara, Turkey kemalondercetin@gmail.com xx - https://orcid.org/0000-0003-0540-2247 
direct shear testing, several attempts to characterize gravel and rock fill materials through large scale laboratory triaxial testing exist (Xiao et. al., 2014). A comprehensive review and discussion of large scale triaxial testing on rockfill materials has been presented by Xiao et. al. (2016) with special emphasis on dilatancy behaviour and grain crushing. Scaling, along with grain crushing effects are also discussed in Frossard et. al. (2012), Asadzadeh and Soroush (2009).

Within the confines of this manuscript, after the introduction of the custom-designed and made large scale direct shear box apparatus, the discussion of test results performed on poorly and well graded Murat River, Muş gravels will be discussed, followed by comparative discussions with available literature. The scope of this technical note is defined as not to assess a new problem, but to present high quality test data regarding a problem, where i) laboratory data is limited and ii) a consensus has not been reached yet.

\section{DIRECT SHEAR BOX FRAME AND APPARATUS}

A custom-designed and made direct shear box frame with $600 \mathrm{~mm}$ x $600 \mathrm{~mm}$ plan dimensions and height of $800 \mathrm{~mm}$ has been designed for the purpose. Figure 1 shows the direct shear box testing system used in this study.
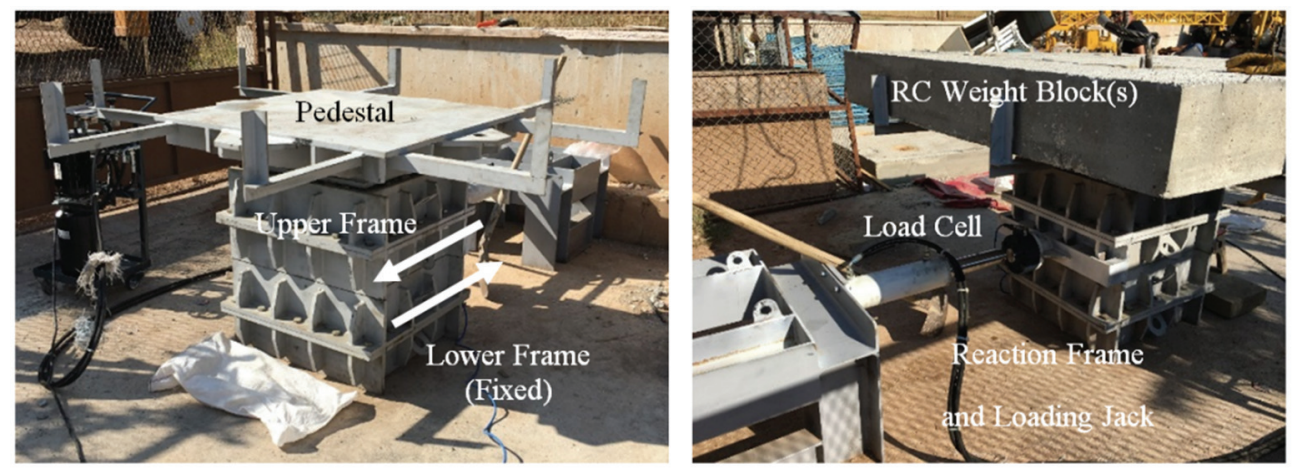

Figure 1 - Direct Shear Box testing system used in this study

Thickness of each frame element was selected as $200 \mathrm{~mm}$, to enable specimen preparations using different compaction procedures (layer thickness, equipment use, etc.). A total number of 4 frame pieces; two lower and upper pieces internally bound were used. The interface between lower and upper frame elements constituted the shearing plane. The plan dimensions of the top cap were selected as $580 \mathrm{~mm}$ x $580 \mathrm{~mm}$ in order to enable proper placement with minimum disturbance. The platform was then expanded with the addition of steel frame elements and to reach to $1100 \mathrm{~mm} \times 1100 \mathrm{~mm}$ to plan dimensions. It is instrumented via a single foil strain gauge type load cell having $200 \mathrm{kN}$ measurement capacity, 2 symmetricallyplaced vertical displacement transducers of $50 \mathrm{~mm}$ capacity and again 2 symmetricallyplaced horizontal displacement transducers of $150 \mathrm{~mm}$ capacity. A sampling interval of $8 \mathrm{~Hz}$ was preferred during the tests. 


\section{SAMPLE CHARACTERISTICS AND SPECIMEN PREPARATION}

On the samples prepared, a series of soil classification tests including sieve analyses and specific gravity tests, was performed. Soil samples are classified as "GW" or "GP" (well graded gravels or poorly graded gravels) in conformity with Unified Soil Classification System (USCS), with $\mathrm{D}_{10}, \mathrm{D}_{30}$ and $\mathrm{D}_{60}$ values varying in the ranges of $8.29-12.49 \mathrm{~mm}$, $17.48-24.24 \mathrm{~mm}$ and $34.94-40.26 \mathrm{~mm}$, respectively. $\mathrm{C}_{\mathrm{u}}$ (coefficient of uniformity) and $\mathrm{C}_{\mathrm{c}}$ (coefficient of curvature) values are estimated to fall in the range of $3.22-4.21$ and $1.06-$ 1.17 , respectively. The average specific gravity value was calculated as $G_{s}=2.72$. A number of representative samples with varying degrees of roundness was randomly selected. Their Roundness Index (RI) (Wadell, 1932) and corresponding classification in accordance with (Powers, 1953) are estimated as 0.18 (very angular - angular with low sphericity), 0.24 (angular - sub angular with low sphericity), 0.30 (sub angular with low sphericity) and 0.76 (well-rounded with low sphericity) respectively, addressing the presence of particles with wide range of roundness in the granular mix. For the purpose of producing homogeneous specimens at the target dry density, the sample preparation process was controlled via vibratory equipment capable of providing constant energy / duration. The thicknesses of compacted layers and the duration of compaction was controlled to achieve four different target densities. A total number of twelve tests (four different densities x 3 different normal stresses) were performed. The last (fourth) set of the large scale shear box tests was conducted under "wet" conditions. The calculated dry unit weights for the Sets 1 through 4 are estimated as $17.44 \mathrm{kN} / \mathrm{m}^{3}, 18.77 \mathrm{kN} / \mathrm{m}^{3}, 18.49 \mathrm{kN} / \mathrm{m}^{3}$ and $17.99 \mathrm{kN} / \mathrm{m}^{3}$ respectively. Initial void ratios $\left(\mathrm{e}_{0}\right)$ before the application of normal stresses are estimated as $0.53,0.42,0.44$ and 0.48 , accordingly. Minimum dry unit weight and maximum void ratio values were estimated as $16.09 \mathrm{kN} / \mathrm{m}^{3}$ and 0.66 . Similarly, the maximum dry unit weight and minimum void ratio values were estimated as $19.29 \mathrm{kN} / \mathrm{m}^{3}$ and 0.41 . On the basis of these, relative densities $\left(D_{R}\right)$ of samples were estimated to vary in the range of 48 to $96 \%$, covering the density range extending from relatively loose to dense.

\section{TEST RESULTS AND THEIR INTERPRETATIONS}

Test results are presented in the form of three way plots, as shown in Figure 2. Three-way plots enable to consistently follow the shear stress - normal stress - shear displacements throughout the test. Peak tangent angle of shear resistance was simply estimated by fitting a linear failure line on the basis of Mohr-Coulomb failure criterion, with regression forced to a cohesion intercept value of $c=0$, which is judged to be an acceptable assumption for clean gravels. Similarly, peak secant angle of shearing resistance was also estimated by fitting linear failure envelope to failure Mohr circle of each test, again with $\mathrm{c}=0$. Additionally, maximum dilation angles were estimated from the ratio of shear (lateral) displacement to volumetric (vertical) displacement rates, consistent with the principles of dilation and plasticity theorems (e.g.: Bolton 1986, Vermeer and de Borst 1984). A summary of test results is presented in Table 1. During Test Set 1-1, the vertical displacement transducers were observed to be dislocated; hence corresponding vertical displacement data was excluded in Figure 2. The stress values shown in Figure 2 are estimated after the application of area corrections. Calculation of the dilation angle is based on the assumption that the horizontal plane of the shear box is a zero extension line (Roscoe, 1970). Due to suppression of dilatancy 
with increasing stresses, secant friction angles are mostly observed to be reduced with increasing normal stresses.
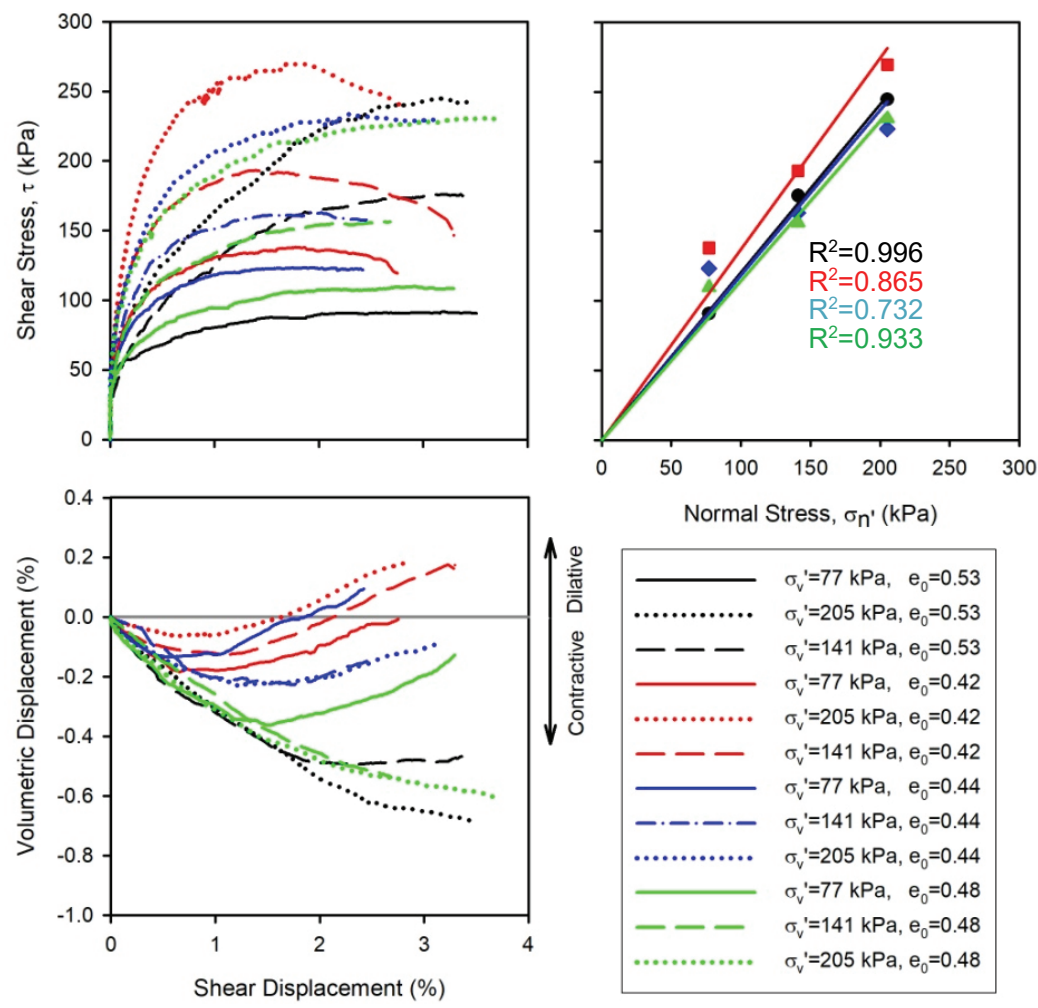

Figure 2 - Three way plots summarizing shear and volumetric deformation responses for the samples with initial void ratios of 0.53, 0.42, 0.44 and 0.48 (Sets 1-4)

\section{COMPARISONS WITH AVAILABLE LITERATURE AND CONCLUSIONS}

The estimated peak secant angles of shearing resistance are comparatively shown in Figure 3 with the typical ranges given for rockfills, gravels and sands by Terzaghi, Peck and Mesri (1996). Estimated peak secant angles of shearing resistance and initial porosity $\left(\mathrm{n}_{0}\right)$, of samples, which vary in the range of 49-61 degrees, and 0.30-0.35, respectively, compare well with the values recommended for sandy gravels and rockfills. They are also found to be in agreement with other studies available in the literature (Simoni and Houlsby, 2006); but, significantly larger than the values recommended by Navfac DM 7.01 for well graded gravels. Significantly lower angles of shearing resistances by Navfac DM 7.01 can be judged to be reasonable, if these values are i) recommended as tangent but not secant angles of shearing resistances, ii) applicable to larger stress ranges, iii) already penalized by partial material factors, widely preferred to be used in design. Unfortunately, due to lack of clear documentation and definitions provided by Navfac DM 7.01, discussions attempting to resolve these differences cannot go beyond crude speculations; hence skipped herein. 
Table 1 - Summary of results for large scale direct shear box tests on unsorted fill material

\begin{tabular}{|c|c|c|c|c|c|c|c|}
\hline Test No & $\begin{array}{c}\text { Normal } \\
\text { Stress } \\
(\mathrm{kPa})\end{array}$ & $\begin{array}{l}\text { Shear } \\
\text { Strength } \\
\text { (kPa) }\end{array}$ & $\begin{array}{c}\text { Shear } \\
\text { (Lateral) } \\
\text { Displ. at } \\
\text { Failure } \\
\text { (\%) }\end{array}$ & $\begin{array}{c}\text { Volumetric } \\
\text { (Vertical) } \\
\text { Displ. at } \\
\text { Failure (\%)** }\end{array}$ & $\begin{array}{c}\text { Peak } \\
\text { Secant } \\
\text { Angle of } \\
\text { Shearing } \\
\text { Resist, } \phi_{s}\left({ }^{\left({ }^{\prime}\right.}\right)\end{array}$ & $\begin{array}{c}\text { Peak } \\
\text { Tangent } \\
\text { Angle of } \\
\text { Shearing } \\
\text { Resist, } \phi_{t}\left({ }^{(}\right)\end{array}$ & $\begin{array}{c}\text { Peak } \\
\text { Angle of } \\
\text { Dilation } \\
\psi_{\max }\left({ }^{0}\right)\end{array}$ \\
\hline Test 1-1 & 77.1 & 90.7 & 3.51 & - & 49.6 & \multirow{3}{*}{50.3} & - \\
\hline Test $1-2$ & 141.1 & 175.6 & 3.45 & -0.47 & 51.2 & & - \\
\hline Test $1-3$ & 205.2 & 244.5 & 3.47 & -0.68 & 50.0 & & - \\
\hline Test 2-1 & 77.1 & 138.0 & 1.76 & -0.13 & 60.8 & \multirow{3}{*}{53.9} & 10.0 \\
\hline Test 2-2 & 141.1 & 193.3 & 1.40 & -0.11 & 53.9 & & 10.5 \\
\hline Test 2-3 & 205.2 & 269.4 & 1.77 & 0.02 & 52.7 & & 11.2 \\
\hline Test 3-1 & 77.1 & 123.4 & 1.86 & 0.00 & 58.0 & \multirow{3}{*}{49.8} & 16.0 \\
\hline Test 3-2 & 141.1 & 163.2 & 1.91 & -0.22 & 49.2 & & 13.7 \\
\hline Test 3-3 & 205.2 & 233.5 & 2.29 & -0.18 & 48.7 & & 13.2 \\
\hline Test 4-1* & 77.1 & 109.7 & 2.93 & -0.21 & 54.9 & \multirow{3}{*}{48.9} & 16.8 \\
\hline Test $4-2^{*}$ & 141.1 & 156.2 & 2.63 & -0.53 & 47.9 & & - \\
\hline Test $4-3 *$ & 205.2 & 230.8 & 3.55 & -0.59 & 48.4 & & - \\
\hline
\end{tabular}

*: Performed under wet conditions, **: Negative values indicate contractive behaviour

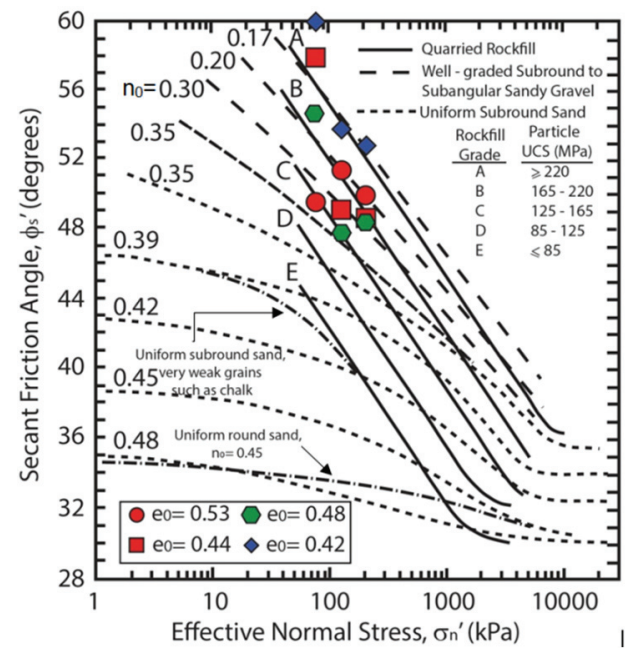

(a)

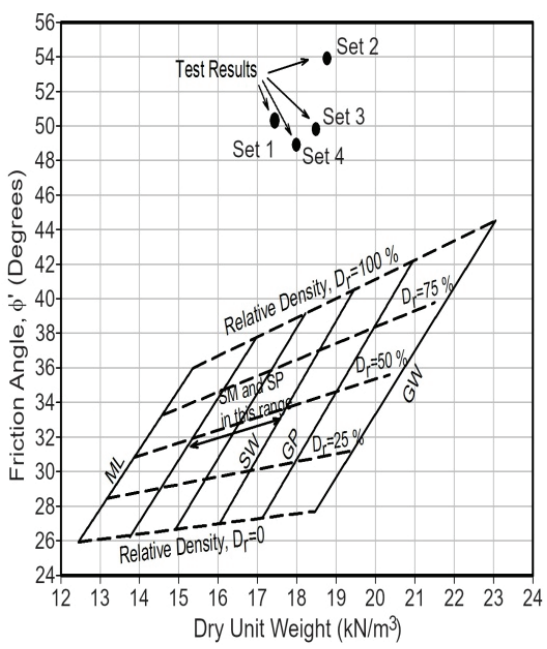

(b)

Figure 3 - The estimated peak secant angles of shearing resistance compared with typical ranges of friction angle for rockfills, gravels and sands as suggested by (a) Terzaghi, Peck and Mesri (1996) and (b) NavFac DM 7.01 
The peak angles of dilation values at failure are estimated to vary in the range of 10 to 16 degrees, which are observed to be consistent with available literature (Simoni and Houlsby, 2006). Similarly, the minimum void ratio values reported herein from large scale direct shear tests (approximately in the range of $0.35-0.40$ ) are judged to be also consistent with the $\mathrm{e}_{\min }$ dataset presented by Simoni and Houlsby (2006). Last but not least, similar conclusions can be made for peak secant angles of shearing resistance and relative density relations; although the nature of coarse grained soil characteristics slightly differ in this study. As the concluding remark, the test results are concluded to be in coherency with available literature, other than the "friction angle" recommendations of Navfac DM 7.01 for well graded gravels.

\section{References}

[1] Asadzadeh, M., Soroush, A., Direct Shear Testing on a Rockfill Material. Arabian Journal for Science and Engineering, Vol. 34, No. 2B, 379-396, 2009.

[2] Bolton, M. D., The strength and dilatancy of sands. Geotechnique, Vol. 36, No. 1, 65$78,1986$.

[3] Frossard, E., Hu, W., Dano, C., Hicher, P. Y., Rockfill shear strength evaluation: a rational method based on size effects. Géotechnique, Thomas Telford, 62 (5), pp.415427, 2012.

[4] Li, X. Z, Li, J. L., Deng, H. F., In-Situ Direct Shear Test Research of Rock and Soil of Typical Bank Slope in Three Gorges Reservoir Area. Electronic Journal of Geotechnical Engineering, Vol. 19, Bundle K, 2523-2534, 2014.

[5] Liu, S. H., Application of in situ direct shear device to shear strength measurement of rockfill materials. Water Science and Engineering, 2 (3): 48-57, 2009.

[6] Liu, S. H., Xiao, G. Y., Yang, J. Z., and Wu, G. Y, New in-situ direct shear tests on rockfill materials at Yixing Pumped Storage Power Station Project. Chinese Journal of Geotechnical Engineering, 26(6), 772-776, 2004, (in Chinese).

[7] Matsuoka, H., Liu, S. H., Sun, D., and Nishikata, U., Development of a new in-situ direct shear test. Geotechnical Testing Journal, 24(1), 92-102, 2001. [doi:10.1520/GTJ11285J]

[8] NAVFAC, Soil Mechanics Design Manual 7.01. Naval Facilities Engineering Command, 1986.

[9] Powers, M.C., A new roundness scale for sedimentary particles. Journal of Sedimentary Petrology, 23:117-119, 1953.

[10] Roscoe, K.H., The Influence of Strains in Soil Mechanics, Tenth Rankine Lecture, Geotechnique, Vol. 20, No. 2, pp. 129-170.

[11] Simoni, A., Houlsby, G.T., The Direct Shear Strength and Dilatancy of Sand-gravel Mixtures. Geological and Geotechnical Engineering, Vol. 24, pp. 523-549, 2006.

[12] Terzaghi, K., Peck, R. B., Mesri, G., Soil Mechanics in Engineering Practice, $3^{\text {rd }}$ Edition, 1996, John Wiley \& Sons Inc. 
[13] Vasistha, Y., Gupta, A. K., Kanwar, V., Prediction of Shear Strength Parameters of Two Rockfill Materials. Electronic Journal of Geotechnical Engineering, Vol. 17, Bundle W, 3221 - 3232, 2012.

[14] Vermeer, P. A., de Borst, R., Non-associated plasticity for soils, concrete and rock. Heron, Delft University of Technology, Vol. 29, No.3, 1984.

[15] Wadell, H., Volume, shape and roundness of rock particles. Journal of Geology, 40:443-451, 1932.

[16] Wang, J. J., Yang, Y., Chai, H.J., Strength of a Roller Compacted Rockfill Sandstone from In-Situ Direct Shear Test. Soil Mechanics and Foundation Engineering, Vol. 53, No.1, March 2016.

[17] Xiao, Y., Liu, H., Chen, Y., Jiang, J., Strength and Deformation of Rockfill Material Based on Large-Scale Triaxial Compression Tests. I: Influences of Density and Pressure. ASCE Journal of Geotechnical and Geoenvironmental Engineering, Vol. 140, No:12, December 2014.

[18] Xiao, Y., Liu, H., Zhang, W., Liu, H., Yin, F., Wang, Y., Testing and modeling of rockfill materials: A review. Journal of Rock Mechanics and Geotechnical Engineering, Vol. 8., 415-422, 2016. 
